\title{
Towards Developing Standards for the Zakat Administration in the Republic of Sudan
}

\author{
Mahmoud Ghalib Elmaghrabi, \\ Mustafa Omar Mohammed, \\ Muhammad Tahir Jan
}

International Islamic University Malaysia (IIUM), Malaysia

\begin{abstract}
Zakat has a long history of helping poor and disadvantaged groups. However, Zakat institutions face numerous challenges in achieving their socio-economic objective: equitable distribution of resources. The aim of this study is to highlight the challenges hindering managerial efficiency in contemporary Zakat institutions as well as identify ways to improve managerial efficiency. Focusing the case on Sudan, this paper identifies the constraints facing the Zakat institution, from the macro perspective as well as from the managerial viewpoint. By using secondary sources, this paper found that inefficiencies such as ineffective collection and distribution, lack of coordination and mismanagement are some of the impediments causing inefficiency of Zakat collection and distribution. Furthermore, the paper suggests that standards constitute an instrument for the Zakat intuition to manage and enhance its efficiency as well as having the ability to guide Zakat in the right direction.
\end{abstract}

Keywords: Zakat Challenges; Efficiency; Standards; Sudan; Zakat Governance; Zakat Institutions 


\section{Introduction}

Today's organizations operate in a fast-changing business environment. Non-profit organisations and religious organisations are no exception. The world is also witnessing a series of changes for all organisations caused by the COVID-19 pandemic. The role of charity and religious organisations becomes increasingly crucial during these troubled times. Zakat institutions are non-profit organisations that collect and distribute alms. Zakat institutions differ from the private and public sectors in terms of motivation, operation, sources of funding and contribution to public good. Unlike other non-profit organisations, Zakat institutions exist to provide social welfare and build social capital in civil society using a religiously-inspired tax collected from Muslims. The collection of Zakat is voluntary in most countries and it is mandatory in six Muslim majority countries: Malaysia, Pakistan, Libya, Saudi Arabia, Sudan and Yemen (Abdel Mohsin, 2020). This paper mainly focuses on Zakat administration in Sudan.

As one of the five pillars of Islam, Zakat plays an important role on promoting a more equitable distribution of wealth while also creating a sense of solidarity amongst Muslims. In Sudan, Zakat has played a vital role in alleviating poverty. As the main source of targeted social safety net interventions, it funds 87 percent of the Sudanese government's "social safety net intervention", targeting poor and financially vulnerable households (Kjellgren et al., 2014, p. 24). Initiated as a voluntary payment in 1980, Zakat has been mandatory for Sudanese since 1984 and Sudan has constitutional provisions for Zakat management (Powell, 2010). Although Sudan has established Islamic financial services (Abdel Mohsin et al., 2017) and has a long history of Zakat collection and distribution, little is known about Zakat administration in the country. It important to evaluate the efficiency and governance of Zakat institutions to make sure that the Islamic financial system is functioning effectively and achieves the noble objectives of alms giving (Wahab and Abdul Rahman, 2011).

There is a growing stream of literature examining the efficiency of Zakat administration, with some scholars questioning the distributive impact of Zakat (Kahf, 1989) while some criticise the ambiguity around Zakat governance (Kuran, 2020; Wahab and Abdul Rahman, 2011). One of many ways to improve efficiency and governance of Zakat is by developing adequate standards. Standards have been long recognised as an effective tool to maintain good practice. Usually written in a formal document that combine best practices in the industry, standards represent agreed guidelines, specifications, or principles. Organisations use standards to demonstrate that their operations and products meet the agreed criteria, and that their governance and accounting practices are consistent with the industry standards (British Standards Institute, 2015). However, not many studies examine the governance and standards of Zakat institutions.

Therefore, the objectives of this paper are twofold: first, to highlight the challenges hindering the efficiency of Zakat management in Sudan; and second, to identify the role of standards in managing Zakat. With an emphasis on standards and Zakat governance, this paper reviews and synthesises scholarly works on Zakat, including peer-reviewed journal articles, industry reports, reports published in newspapers, and

International Journal of Management and Applied Research, 2020, Vol. 7, No. 2 
edited book collections. This paper is structured as below: the first section discusses the challenges facing Zakat institutions across the globe and compares these with Zakat institutions in Sudan. The second section reviews the use of standards in nonprofit organisations, which builds the foundation for the following section: standards as a code of practice for Zakat institutions in Sudan. The last section summarises this paper and presents concluding remarks.

\section{Challenges facing the Zakat institutions}

An abundance of research has been conducted on Zakat institutions, both theoretically and empirically. Prior studies remark on the importance of efficient collection and distribution of Zakat to ensure a fair and sustainable redistribution of wealth. Shehata (1994), for instance, examined the jurisprudential interpretations of Islamic laws regarding Zakat funds, including the entitlement criteria for receiving Zakat. Shehata (1994) notes that Zakat is at the discretion of Muslims and ruler over the Zakat funds, especially in terms of equitable Zakat distribution. It is clear that Zakat is intended to fund eight types of broadly defined constituencies: 1) the poor, 2) the needy, 3) Zakat collectors, 4) those who converted to Islam, 5) freeing captives, 6) defaulting debtors, 7) those who are on the path of Allah, and 8) travellers. However, there is a lack of specificity regarding the ratios in assisting these eight groups and uncertainty in defining beneficiaries.

Zakat appears 32 times in the Holy Quran (Kuran, 2020) but the Quran did not specify the division of resources among the named eight beneficiary categories. The ambiguity concerning the eligibility criteria and its dimensions creates difficulty in distributing Zakat funds evenly. For example, a wealthy traveller could claim Zakat to cover transportation and accommodation expenses; however, disbursing Zakat to wealthy travellers deviates from the socio-economic goal of Zakat -- to redistribute wealth. For these reasons, the majority of the Islamic schools of jurisprudence, except for Shafi School, are of the view that it is not necessary to distribute Zakat among all eight categories (Shehata, 1994).

In addition to the ambiguity regarding Zakat disbursement, the Quran also did not specify particularities of Zakat governance: should a Zakat payment be made to a state agent or an intermediary? Little is known regarding the actual Zakat collection and disbursement practices in the early modern period. The limited coverage on the early practices on Zakat administration can be explained by two reasons: 1) Zakat was contributed voluntarily and thus there are no official records documenting its collection and use; 2) there had been little or no commitment to enforcing it (Kuran, 2012). Beginning as an informal and voluntary contribution among the earliest converts, Zakat became institutionalised as the Muslim community grew substantially (Kuran, 2012). However, Zakat institutions also experience growing pains like most organisations. There is a transition from a laissez-faire community-run charity to professionally managed institutional arrangements. Therefore, there is a need to enhance professionalism and efficiency in managing Zakat (Islamic Research and Training Institute, 2015). Although the operational activities of Zakat institutions are based on Islamic laws, the contemporary practice of Zakat management differs across the globe.

International Journal of Management and Applied Research, 2020, Vol. 7, No. 2 
The absence of standards in Zakat administration leads to different approaches when collecting and distributing Zakat. Originally, Zakat was levied on individuals in the preindustrial Islamic economy, but contemporary Zakat collectors extend the obligation to corporations in some countries such as the Maldives (Muneeza, 2017) and Malaysia (Yusuf and Derus, 2013). Countries with a compulsory Zakat system differ in their definition of Zakatable assets or income. In Sudan, for instance, Zakatable income includes rental (Abdel Mohsin, 2020) that is not included in other countries. Islamic Research and Training Institute (2015) pointed out that the case for having a universally accepted definition of Zakatable income is weak, because the Zakat system must retain sufficient flexibility to accommodate social needs in different communities. The success or failure of Zakat institutions is not dependent solely on the definition of Zakatable income but also rests on professionalism in fund-raising and continuous improvements in governance.

The voluntary nature of Zakat collection and the prohibition on charging interest on late payment in Islamic law creates barriers for Zakat collectors. For example, Zakat administration in Malaysia is under the authority of state government, but there is no law enforcing Zakat contribution and Zakat collection other than at the discretion of Muslims (Yusuf and Derus, 2013). The enforcement of the Zakat obligation is not mentioned in the Qurananic verses, and the Quran does not go beyond the eight recipient categories in terms of Zakat disbursement (Kuran, 2020). Zakat institutions have priority in distributing Zakat and allocating Zakat resources according to their discretion (Islamic Research and Training Institute, 2015; Kuran, 2020; Muneeza, 2017). Another constraint of Zakat collection concerns insufficient awareness of Zakat because its underlying principles and calculation are rarely taught by religious teachers (Muneeza, 2017). According to the rule of paying Zakat, Muslims must pay $2.5 \%$ of their wealth, which comes from a wide range of liquid assets, livestock, precious metals (e.g. gold and silver), and agricultural produce. However, the rate applied to Zakatable wealth is capped, thereby preventing individuals from paying more and restricting fiscal capacity (Kuran, 2020).

Perhaps the greatest challenge facing Zakat institutions is to modernise and institutionalise the traditional Zakat system. The vast majority of literature comments on the inefficiencies of Zakat administration in various countries, including inefficient collection and distribution (Basir et al., 2017; Bilo and Machado, 2020; Kjellgren et al., 2014), lack of transparency (Ali and Hatta, 2014; Bilo and Machado, 2020; Kjellgren et al., 2014), absence of sophiticated IT infrastrcture (Kjellgren et al., 2014; Muneeza, 2017), mismanagement (Ali and Hatta, 2014), lack of adequate managerial and administrative knowledge (Ahmad, 2019; Muneeza, 2017), poor documentation (Abdel Mohsin, 2020), and the lack of coordination between central and regional bodies (Ahmad, 2019; Bilo and Machado, 2020; Kjellgren et al., 2014; Muneeza, 2017).

\section{Macroeconomic context of Sudan and Zakat Chamber}

Sudan is characterised as a low-income, food-deficit country (Turkawi, 2015), which has had not only 40 years of civil war but also natural disasters such as floods and

International Journal of Management and Applied Research, 2020, Vol. 7, No. 2 
drought in the past few decades. The ongoing internal conflict in Sudan has been largely driven by land dispossession, political and socio-cultural marginalisation (Abdelmoneium, 2016). In 2011, the majority of South Sudan voted for secession from Sudan, and became an independent state. The secession of South Sudan had a significant impact on the Sudanese economy. Following the secession, Sudan lost nearly three-quarters of its oil production, half of its fiscal revenues, two-thirds of its international payment capacity, and approximately one-fifth of its natural resources (Kjellgren et al., 2014). In addition to growing unresolved external debts (Turkawi, 2015) and depreciation of the Sudanese currency, Sudan relies on imports of food which further increase inflation (Kjellgren et al., 2014). Given the weak social protection in Sudan, many displaced families struggle to meet basic needs of shelter, food, and healthcare (Abdelmoneium, 2016).

\subsection{Legal background and Zakat Chamber}

According to Powell (2010), Zakat collection in Sudan was made mandatory in 1984 and Sudan affirms state authority to enforce Zakat both in the 1998 Constitution and the 2005 Transitional Constitution. In 1986, the Sudanese Zakat Chamber was established to separate Zakat from other types of taxation (Bilo and Machado, 2020). The Zakat Act of 2001 is a guiding document for Zakat, for instance, chapter three covers Zakat collection, while chapter six deal with violation and penalties (The National Assembly Legislation Zakat Act 2001). The Zakat Chamber operates as a semi-autonomous federal agency and has a workforce of paid employees and volunteers working on Zakat collection and distribution (Bilo and Machado, 2020). Despite Zakat administration being a state affair, Bilo and Machado (2020) note that the budget of Zakat Fund is independent from the Ministry of Finance.

Zakat constitutes a crucial part of providing financial support to the financially vulnerable population of Sudan. Over 80 percent of state interventions in helping Sudanese vulnerable households come from Zakat resources (Kjellgren et al., 2014). Moreover, the authoritarian military regime in Sudan restricts the ability of nongovernmental organisations to work freely (Abdelmoneium, 2016) and by doing so limits financially vulnerable individuals and families to reliance on state interventions.

The Zakat institution in Sudan is a hybrid of public and non-governmental organisation: it is a semi-autonomous agency with the duty of assisting financial disadvantaged households and individuals. However, it lacks the authority to coordinate with other ministers and the ability to enforce violations of Zakat, evasion and avoidance. Chapter six of the Zakat Act covers violation and penalties (The National Assembly Legislation Zakat Act 2001), but it is not clear, how the Sudanese Zakat Chamber can verify compliance with the Zakat Act and ensure timely Zakat payment. Furthermore, enforcement actions are limited to financial penalties, without considering other forms of penalty (e.g. community services, repossession, deduction from pension fund).

Kjellgren et al. (2014) note the following shortcomings facing the Zakat Chamber: inefficient mechanisms of distribution, poor targeting procedures, lack of coordination between all ministers, and inadequate technical assistance. Consistent with the findings

International Journal of Management and Applied Research, 2020, Vol. 7, No. 2 
of Kjellgren et al., (2014), Bilo and Machado (2020) reported that there is an absence of institutional coordination to streamline Zakat interventions. Furthermore, there are overlapping funds (e.g. Zakat fund, student support grant, health insurance fund) helping poor and vulnerable households (Bilo and Machado, 2020). The targeting procedure to identify the poor and extremely poor is not well-organised as local Zakat committees have no access to the database and digitalised list of beneficiaries (Turkawi, 2015). The databases for National Health Insurance and Zakat beneficiaries are also not linked, resulting in obstacles in reaching poor and vulnerable households (Bilo and Machado, 2020). This not only shows a lack of coordination between ministers but also results in inefficient Zakat distribution. Additionally, no information regarding the regularity of receiving Zakat is made available, thus making it difficult to determine whether financial assistance is adequate for Zakat recipients (Kjellgren et al., 2014). There is also an absence of redress mechanisms and an independent task force to investigate complaints (Bilo and Machado, 2020; Kjellgren et al., 2014; Turkawi, 2015). All these factors naturally hinder the efficiency of Zakat disbursement.

Omissions in managing Zakat typically occur due to weak governance structure, incompetent and/or inadequate workforce, absence of policy manuals to ensure proper control, lack of transparency and accountability. In the case of the Zakat institution in Sudan there is also an absence of a code of practice to manage Zakat in a productive manner.

\section{Standards, Efficiency and Zakat Governance}

Standards are a set of requirements or conditions that are widely accepted by organisations sharing similar operational practices (British Standards Institute, 2015). If an organisation adheres to certain standards this gives credibility and reassurance to its stakeholders. Standards are particularly important for international firms having a global presence, as standards function as a blueprint for employees to act and follow. Standards could be seen as an alternative to laws and legislative regulations, characterised with a greater level of flexibility.

Zakat institutions are facing a number of managerial challenges as highlighted in earlier sections. To overcome these challenges, a collective effort must be made. One possible solution is to establish and implement standards that could be used as a benchmark to measure the efficiency of Zakat operations and activities.

One of the widely known authorities in Islamic finance is Accounting and Auditing Organization for Islamic Financial Institutions, (AAOIFI). The accounting standards (AAOIFI, 2015) cover matters specific to the collection and distribution of Zakat funds: Zakatable assets, Zakat rates and rulings on Zakat disbursement. However, AAOIFI has not set up standards for supervision and management of Zakat.

Basir et al. (2017) reported the implementation of the Malaysian Islamic Quality Management System (MS 1900) in the Malacca Zakat Centre. There are 12 steps in the Islamic QMS MS1900: 1) identifying gaps; 2) understanding MS1900; 3) outlined quality policies and objectives; 4) quality committee establishment; 5) management representative establishment; 6) management commitment; 7) documentations; 8)

International Journal of Management and Applied Research, 2020, Vol. 7, No. 2 
determining the quality scope system; 9) implementing MS1900; 10) internal audit; 11) evaluating quality management system performance; 12) surveillance audit. Basir et al. (2017) concluded that the MS1900 implementation in the Malacca Zakat Centre was successful because it not only emphasises religious aspects (prohibition against usury and haram activities) but also technical aspects (documentation) and managerial issues (performance management). However, the Islamic QMS MS1900 is not without limitations: first, it lacks a feedback and complaint mechanism for safeguarding the process of continuous improvement; and second, it has overlapping functions (step 3 and 8). Feedback should be collected from recipients, payees, and employees as part of ensuring quality management. Feedback should be closely realigned with implementation of a redress mechanism which would allow users to file complaints and enable the organisation to investigate complaints.

Using the Basel Core Principles (Bank for International Settlements, 2012) as a reference point, Beik (2015) proposed eighteen core Zakat principles, and categorised these principles under six dimensions: legal foundations, Zakat supervision, Zakat governance, intermediary function, risk management, and Shariah governance. A close examination of these principles suggests that there is a degree of overlap between them which could be minimised. Beik (2015) referred to "Zakat governance" as a set of Shariah-compliant practices coupled with a domestic legal system used to direct and manage a Zakat institution. To a great extent, Beik's "Zakat governance" overlaps with the "Shariah governance" and "legal foundation" dimensions. Nonetheless, Beik's core principles of Zakat note the importance of risk management, governance, Shariah compliance, intermediary function, local legal system, and lastly supervisory and audit functions.

Wahab and Abdul Rahman (2011) proposed a conceptual model of Zakat governance and efficiency. The model consists of two main factors that contribute to efficiency: governance and structural factors. While the governance factor is subdivided into five characteristics (board size, proportion of professionals on board, active board of directors, audit committee and organizational structure), the structural factor is subdivided into three characteristics (privatisation, number of branches, and technology). To a large extent, these characteristics put a greater emphasis on the executive level, with little or no attention on risk management, Shariah compliance, bottom-up communication, and performance management.

\section{Towards Developing Zakat Standards Framework in Sudan}

Some Islamic scholars and researchers suggested certain ways of improving the current Zakat system in Sudan. Kjellgren et al. (2014) pointed out that in order to optimise the impact of Zakat in Sudan, the Zakat Chamber should address such managerial issues as accountability and transparency, monitoring and regular evaluation, and also pursue digitisation of records. Such initiatives would require a reform that goes far beyond annual Zakat collection and distribution, and would ensure more attention to long-term social protection. It also requires periodic assessments measuring the effectiveness of the Zakat disbursement and collection process. Based on the theoretical and empirical studies discussed earlier, we proposed a framework for Zakat governance in Sudan. The theoretical model is shown in Figure 1.

International Journal of Management and Applied Research, 2020, Vol. 7, No. 2 
Figure 1: Zakat Standards Framework

\begin{tabular}{|l|l|l|}
\hline \multicolumn{1}{|c|}{ Plan } & \multicolumn{1}{c|}{ Do } \\
$\begin{array}{l}\text { Set strategic goals and } \\
\text { operational objectives } \\
\text { Identify possible risks } \\
\text { Revise plan if necessary }\end{array}$ & $\begin{array}{l}\text { Devise plan } \\
\text { Coordinate with all } \\
\text { ministers }\end{array}$ \\
\hline \multicolumn{1}{|c|}{ Change } \\
\begin{tabular}{|l|l|} 
Identify necessary \\
changes \\
Make corrections to plan \\
Modify plan and actions \\
accordingly
\end{tabular} \\
\hline
\end{tabular}

The "plan" and "do" phases cover managerial expectations of Zakat institutions, emphasising the importance of good corporate governance and planning, as well as compliance with Shariah laws and the domestic legal system. The strategic planning should not deviate from Shariah principles and should be in line with the socioeconomic objectives that Zakat aims to achieve: equitable distribution of resources.

The later "assess" and "change" phases address supervisory powers, monitoring and auditing functions, risk management, two-way communication, and the need for timely corrective actions. The model has taken account of the obstacles facing Zakat institutions in Sudan:

- the need for greater supervisory attention and adequate resources to deal effectively with local council committees;

- the importance of applying a bottom-up perspective in identifying and taking preemptive action to ensure that the targeted beneficiary groups are being taken care of;

- an increasing focus on effectiveness and transparency in managing Zakat funds.

The proposed model has a degree of flexibility in order to enable it be adapted for different contexts. Although technology adoption and Zakat training are not explicitly mentioned in the model, these two factors can be considered as part of the model. For example, digitalisation of data can be included in the "plan" and "do" phases, which will then be monitored and assessed under "assess" phase and modified accordingly in the "change" phase.

Sound governance relies on effective communication, coordination, and public confidence in individual Zakat collectors and the Zakat system at large. The proposed model does not offer a comprehensive assessment methodology and an alternative

International Journal of Management and Applied Research, 2020, Vol. 7, No. 2 
governance structure for the Sudanese Zakat Chamber. Rather, it puts an emphasis on planning, devising, and monitoring functions. To give greater transparency and public disclosure, the auditing function can be assigned to an independent body in order to provide an unbiased evaluation as part of a monitoring process.

\section{Conclusion}

Zakat was meant to finance humanitarian and religious causes; however, Zakat institutions face a number of barriers in meeting the socio-economic objectives of Zakat. One of the dilemmas facing policymakers in a compulsory Zakat system is to modernise the traditional Zakat system. In the early days, the Zakat system was intended to weaken tribalism in Middle East and replace it with religious brotherhood (Kuran, 2020). The eight beneficiary groups were broadly defined without clear guidelines on managing Zakat institutions. On one hand, such ambiguity provides flexibility in accommodating social needs according to locality; on the other hand, ambiguous requirements can result in Zakat system being inefficient.

Inefficient Zakat collection and distribution, poor monitoring mechanisms, lack of coordination, and mismanagement are the common challenges faced by Zakat institutions across the world. The Sudanese Zakat Chamber is no exception. Kjellgren et al. (2014) reported that there is little information sharing or coordination between the Zakat Chamber and other financial systems in the country, thereby limiting the efficiency of managing Zakat funds and of helping the poor in a more productive manner.

The aim of this paper was to highlight these challenges in optimizing Zakat systems, particularly in the context of Sudan. This paper also discusses the importance of standards and codes of practice in facilitating communication, measuring performance, and maintaining quality. The conceptual framework provided would inform future research and facilitate further development of Zakat centred thinking aiming at its feasibility and applicability in different contexts.

\section{References}

1. Abdel Mohsin, M. I.; Khattab, I. and Alchaar, M. O. (2017), "Sudan Academy for Banking and Financial Sciences and Its Vision As A Hub of Islamic Finance in Africa”, International Journal of Management and Applied Research, Vol. 4, No. 1, pp. 73-89. https://doi.org/10.18646/2056.41.17-007

2. Abdel Mohsin, M. I. (2020), “A Fresh View On Zakah As A Socio-Financial Tool To Promote Ethics, Eliminate Riba And Reduce Poverty", International Journal of Management and Applied Research, Vol. 7, No. 1, pp. 55-71. https://doi.org/10.18646/2056.71.20-004

3. Abdelmoneium, A. (2016), "Internally displaced families in Khartoum-Sudan: challenges and policy implications", International Journal of Migration, Health and Social Care, Vol. 12 No. 4, pp. 252-263. https://doi.org/10.1108/IJMHSC-052015-0017

International Journal of Management and Applied Research, 2020, Vol. 7, No. 2 
4. Accounting and Auditing Organization for Islamic Financial Institutions (AAOIFI) (2015), Shariah Standards, Manama: Accounting and Auditing Organization for Islamic Financial Institutions.

5. Ahmad, M. (2019), “An empirical study of the challenges facing zakat and waqf institutions in Northern Nigeria", ISRA International Journal of Islamic Finance, Vol. 11, No. 2, pp. 338-356. https://doi.org/10.1108/IJIF-04-2018-0044

6. Ali, I. and Hatta, Z. A. (2014), "Zakat as a Poverty Reduction Mechanism Among the Muslim Community: Case Study of Bangladesh, Malaysia, and Indonesia”, Asian Social Work and Policy Review, Vol. 8, No. 1, pp. 59-70. https://doi.org/10.1111/aswp.12025

7. Bank for International Settlements (2012), Core Principles for Effective Banking Supervision, Basel: Bank for International Settlements [Online] available from: https://www.bis.org/publ/bcbs230.pdf [accessed on 7 May 2020].

8. Basir, S.A.; Abdul Ghani Azmi, I.; Syed Ismail, S.H.; Ibrahim, P. and Mohamed, H.A. (2017), "Malaysian Islamic quality management system MS1900: An implementation steps at Malacca Zakat Center", Humanomics, Vol. 33 No. 2, pp. 239-254. https://doi.org/10.1108/H-10-2016-0078

9. Beik, I. S. (2015), "Towards international standardization of zakat system", presented in: 2015 Fiqh Zakat International Conference, Kuala Lumpur: World Zakat Forum and Zakat Collection Center of Malaysia.

10. Bilo, C. and Machado, A.C. (2020), "The role of Zakat in the provision of social protection: A comparison between Jordan and Sudan", International Journal of Sociology and Social Policy, Vol. 40 No. 3/4, pp. 236-248. https://doi.org/10.1108/IJSSP-11-2018-0218

11. British Standards Institutions (BSI) (2015), How standards benefit businesses and the UK economy, UK: British Standards Institutions [Online] Available from: https://www.bsigroup.com/LocalFiles/en-GB/standards/BSI-standards-brochurehow-standards-benefit-businesses-and-the-UK-economy-UK-EN.pdf [Accessed on 3 March 2020].

12. Islamic Research and Training Institute (2015), Islamic Social Finance Report $1436 \mathrm{H}$, Jeddah: Islamic Research and Training Institute.

13. Kahf, M. (1989), "Zakat: unresolved issues in the contemporary fiqh", Journal of Islamic Economics, Vol. 2 No. 1, pp. 1-22.

14. Kjellgren, A.; Jones-Pauly, C. ; El-Tayeb Alyn, H. ; Tadesse, E. and Vermehren, A. (2014), Sudan - social safety assessment. Social protection and labor discussion paper No. 1415. Washington, DC: World Bank Group. [Online] Available from:

International Journal of Management and Applied Research, 2020, Vol. 7, No. 2 
http://documents.worldbank.org/curated/en/615961468159323676/Sudan-socialsafety-assessment [Accessed on 2 March 2020].

15. Kuran, T. (2012), "Political Consequences of the Middle East's Islamic Economic Legacy", in: Aoki, M.; Kuran, and T. Roland, G. (Ed.), Institutions and Comparative Economic Development, UK: Palgrave Macmillan, pp. 99-115.

16. Kuran, T. (2020), “Zakat: Islam's missed opportunity to limit predatory taxation”, Public Choice, Vol. 182, pp. 395-416. https://doi.org/10.1007/s11127-019-00663$\mathrm{x}$

17. Muneeza, A. (2017), "Administration of Zakat on Wealth in Maldives", International Journal of Management and Applied Research, Vol. 4, No. 1, pp. 5871. https://doi.org/10.18646/2056.41.17-006

18. Powell, R. (2010), “Zakat: Drawing Insights for Legal Theory and Economic Policy from Islamic Jurisprudence", University of Pittsburgh Tax Review, Vol. 7, pp. 43-101.

19. Shehata, S.I. (1994), "Limitations on the use of zakah funds in financing socioeconomic infrastructure”, Islamic Economic Studies, Vol. 1 No. 2, pp. 63-78.

20. The National Assembly Legislation Zakat Act (2001), The National Assembly Legislation Zakat Act 2001: Zakat Chamber of Sudan, Republic of Sudan: Zakat Sciences Institute.

21. Turkawi, A. (2015), Social Protection and Safety Nets in Sudan, UK: Institute of Development Studies.

22. Wahab, N.A. and Rahim Abdul Rahman, A. (2011), "A framework to analyse the efficiency and governance of zakat institutions", Journal of Islamic Accounting and Business Research, Vol. 2 No. 1, pp. 43-62.

https://doi.org/10.1108/17590811111129508

23. Yusuf, M. O. and Derus, A. M. (2013), "Measurement model of corporate zakat collection in Malaysia: A test of diffusion of innovation theory", Humanomics, Vol. 29, No. 1, pp. 61 - 74. https://doi.org/10.1108/08288661311299321

International Journal of Management and Applied Research, 2020, Vol. 7, No. 2 